\title{
Efektivitas Air Rebusan dan Air Perasan Lengkuas Merah (Alpinia purpurata K.schum) dalam Menghambat Pertumbuhan Trichophyton rubrum Jamur Penyebab Kutu Air (Tinea pedis)
}

\author{
Eka Sulistianingsih ${ }^{1}$, Mimi Sugiarti ${ }^{2}$ \\ ${ }^{1,2}$ Jurusan Analis Kesehatan, Politeknik Kesehatan Tanjungkarang \\ Email: sulistianingsiheka@ymail.com
}

\begin{abstract}
Effectiveness of Water Decoction and Red Galangal Juice (Alpinia purpurata K.Schum) in Inhibiting the Growth of Trichophyton rubrum Fungi Causes of Water Flea (Tinea pedis). Tinea pedis is dermatophytosis in the feet, especially between the fingers and soles of the feet. Chronic fungal infections in the form of peeling and skin rupture are the main manifestations, accompanied by pain and itching. Antifungal drugs have limitations, such as a narrow spectrum of antifungals, adverse effects on certain tissues and resistance to certain antifungals. One of the plants that are used for treatment is red-angled Galangal (Alpinia purpurata K.Schum). The research objective was to compare the effectiveness of boiled water and red galangal juice (Alpinia purpurata K.schum) in inhibiting the growth of fungus Trichophyton rubrum which causes water flea (Tinea pedis). The research was experimental with a completely randomized design (CRD) design. The independent variable is red galangal juice (Alpinia purpurata K.schum) and red galangal boiled water (Alpinia purpurata K.schum) with a concentration of $10 \%, 20 \%, 30 \%, 40 \%, 50 \%, 60 \%, 70 \%, 80 \%, 90 \%, 100 \%$ and the dependent variable is the growth of fungus Trichophyton rubrum. Data analysis used the ANOVA test, followed by the BNT test (Smallest Real Difference) and T-test.The results showed that red galangal boiled water (Alpinia purpurata K.schum) did not have the ability to inhibit the growth of Trichophyton rubrum fungi. Red galangal juice (Alpinia purpurata K.schum) has the ability to inhibit the growth of fungi Trichophyton rubrum and the minimum concentration that can inhibit the growth of fungi Trichophyton rubrum is $10 \%$ with a mean inhibitory zone of $24.37 \mathrm{~mm}$.
\end{abstract}

Keywords: Boiled water, Juice water, Red galangal, Trichophyton rubrum

\begin{abstract}
Abstrak: Efektivitas Air Rebusan dan Air Perasan Lengkuas Merah (Alpinia purpurata K.Schum) dalam Menghambat Pertumbuhan Trichophyton rubrum Jamur Penyebab Kutu Air (Tinea pedis). Tinea pedis merupakan dermatofitosis pada kaki, terutama sela jari dan telapak kaki. Infeksi jamur kronik berupa pengelupasan dan pecahnya kulit merupakan manifestasi utama, disertai rasa nyeri dan gatal. Obat antijamur mempunyai keterbatasan, seperti spektrum antijamur yang sempit, dampak buruk pada jaringan tertentu dan resisten terhadap antijamur tertentu. Salah satu tumbuhan yang dimanfaatkan untuk pengobatan adalah Lengkuas berimpang merah (Alpinia purpurata K.Schum). Tujuan penelitian mengetahui perbandingan efektivitas air rebusan dan air perasan lengkuas merah (Alpinia purpurata K.schum) dalam menghambat pertumbuhan jamur Trichophyton rubrum penyebab kutu air (Tinea pedis). Penelitian bersifat eksperimental dengan Rancangan Acak Lengkap (RAL). Variabel bebas berupa air perasan lengkuas merah (Alpinia purpurata K.schum) serta air rebusan lengkuas merah (Alpinia purpurata K.schum) dengan konsentrasi $10 \%, 20 \%, 30 \%, 40 \%, 50 \%, 60 \%, 70 \%, 80 \%, 90 \%, 100 \%$ dan variabel terikat berupa pertumbuhan jamur Trichophyton rubrum. Analisa data menggunakan uji ANOVA, dilanjutkan uji BNT (Beda Nyata Terkecil) dan uji T. Hasil penelitian menunjukkan air rebusan lengkuas merah (Alpinia purpurata K.schum) tidak mempunyai kemampuan dalam menghambat pertumbuhan jamur Trichophyton rubrum. Air perasan lengkuas merah (Alpinia purpurata K.schum) mempunyai kemampuan dalam menghambat pertumbuhan jamur Trichophyton rubrum dan konsentrasi minimum yang dapat menghambat pertumbuhan jamur Trichophyton rubrum adalah $10 \%$ dengan rerata zona hambat sebesar $24,37 \mathrm{~mm}$.
\end{abstract}

Kata kunci: Air rebusan, Air perasan, Lengkuas merah, Trichophyton rubrum

Dermatofitosis merupakan penyakit yang disebabkan oleh jamur golongan dermatofita, yaitu Microsporum, Trichophyton dan
Epidermophyton. Infeksi ini dapat menetap dan sangat menggangu, infeksi tersebut tidak melemahkan dan membahayakan jiwa namun 
jutaan rupiah dihabiskan setiap tahun untuk pengobatan infeksi tersebut (Jawetz, 2008).

Telah dilakukan penelitian retrospektif di Poliklinik Kulit dan Kelamin serta Instalansi Rekam Medik di RSUP Prof. Dr. D. Kandou Manado tahun 2013 didapatkan 153 (3,7\%) kasus dermatofitosis dari total 4099 kasus penyakit kulit dan kelamin di Poliklinik Kulit dan Kelamin. Hasil ini menunjukkan peningkatan dari penelitian sebelumnya di RSUP Prof. Dr. D. Kandou Manado periode Januari-Desember 2012 dengan persentase kasus dermatofitosis saat itu sebesar 1,6\% (Sondakh, 2016). Dermatofitosis dibagi berdasarkan lokalisasi kelainan pada tubuh manusia yaitu tinea kapitis, tinea korporis, tinea favosa, tinea imbrikata, tinea krusis, tinea pedis, tinea ungium, dan tinea barbae (Sutanto, 2008).

Penyakit infeksi oleh jamur biasanya diobati dengan mengggunakan obat-obatan antijamur yang sebagian besar mempunyai keterbatasan, seperti efek samping yang besar, spektrum anti jamur yang sempit, penetrasi yang buruk pada jaringan tertentu dan jamur yang resisten terhadap antijamur tertentu (Jawetz, 2008). Resistensi antijamur telah ditemukan terhadap beberapa jamur diantaranya, spesies Candida yang resisten terhadap flukanazol, Aspergillus flavus resisten terhadap amfetorisin B, Candida glabrata resisten terhadap flukanazol memperlihatkan resistensi silang tehadap terbinafin serta Saccharomyces cerevisiae resisten terhadap echinocandis (Apsari, 2013). Salah satu upaya mengatasi masalah dalam hal ini adalah meningkatkan bentuk obat tradisional dengan memanfaatkan tumbuhan, yang memiliki efek samping obat tradisional yang relatif kecil dibandingkan obat kimia dan harganya yang lebih terjangkau oleh masyarakat luas.

Salah satu tumbuhan yang dapat dimanfaatkan untuk pengobatan adalah lengkuas merah. Lengkuas berimpang merah lebih sering digunakan sebagai bahan ramuan obat tradisional. Sesuai dengan penelitian Violita, 2013 tentang perbandingan uji efektifitas air perasan rimpang lengkuas merah dan rimpang lengkuas putih terhadap jamur Malassezia furfurpenyebab penyakit panu, didapatkan konsentrasi minimum lengkuas merah dalam menghambat adalah $20 \%$ dengan zona hambat $11,25 \mathrm{~mm}$ dan pada lengkuas putih didapatkan konstrasi minimum dalam menghambat adalah $20 \%$ dengan zona hambat $10 \mathrm{~mm}$, rimpang lengkuas merah menunjukkan daya anti fungi lebih besar dari pada rimpang lengkuas putih. Bahan kimia yang terkandung dalam lengkuas yaitu 1'-asetoksikavikol asetat, 1'asetoksieugenol asetat, kaiofilin oksida, karriofillenol, 7-hetadekana, kuersetin 3-metil eter, ramnositrin, dan 7-hidroksi-3-5dimetoksiflavon. Rimpang lengkuas mengandung minyak astiri $1 \%$ dengan kandungan euganol. Kandungan yang lain adalah galangin, galangol, metilsinamat, sineol, kaemferida, amilum, hidrates, sesuiterpen, kadinena, polifenol, flavonoid,dan damar (Baheramsyah, 2014).

Farmakologi China dan pengobatan tradisional lainnya menjelaskan, lengkuas merah memiliki sifat antijamur dan antikembung (Priyoto, 2014). Komponen yang terdapat pada golongan Alpinia adalah alpinetin, yang merupakan jenis flavanon yang dikenal sebagai senyawa fungistatik dan fungisida. Komponen lainnya sebagai antimikroba dalam rempahrempah adalah senyawa fenolik (Budiarti, 2006). Penggunaanya sebagai obat tradisional, rimpang lengkuas merah dapat diolah dengan cara yaitu direbus dan diperas. Masyarakat dapat langsung mempraktekkan dengan mudah dan efesien.

\section{METODE}

Penelitian yang dilakukan bersifat eksperimental dengan desain penelitian berupa Rancangan Acak Lengkap (RAL). Penelitian yang dilakukan bersifat eksperimental dengan desain penelitian berupa Rancangan Acak Lengkap (RAL). Terdapat dua variabel yaitu variabel bebas berupa air perasan lengkuas merah (Alpinia purpurata K.schum) serta air rebusan lengkuas merah (Alpinia purpurata K.schum) dengan konsentrasi 10\%, 20\%, 30\%, 40\%, 50\%, $60 \%, 70 \%, 80 \%, 90 \%, 100 \%$ dan variabel terikat berupa pertumbuhan jamur Trichophyton rubrum. Sebagai kontrol negatifnya adalah aquades steril dan kontrol positif adalah ketokenazol 2\%. Pemeriksaan menggunakan metode difusi agar cara Kirby Bauerdengan melihat zona hambat yang terbentuk. Pengulangan yang dilakukan sebanyak 3 kali dari hasil perhitungan yang diperoleh menggunakan rumus : $(t-1)(r-1) \geq$ 15.

Lengkuas merah yang didapatkan dideterminasi di Laboratorium Botani Jurusan Biologi Fakultas Matematika dan Ilmu Pengetahuan Alam Universitas Lampung, Sedangkan strain murni jamur Trichophyton rubrum didapatkan dari Fakultas Kedokteran Universitas Indonesia.

Prosedur penelitian yang dilakukan adalah:

a. Pembuatan larutan uji dan pengenceran larutan uji menjadi konsentrasi 10\%, 20\%, $30 \%, 40 \%, 50 \%, 60 \%, 70 \%, 80 \%, 90 \%$, $100 \%$. Pembuatan larutan uji perasan yaitu 
250 gram rimpang lengkuas merah (Alpinia purpurata K.schum) dicuci dengan air mengalir kemudian ditiriskan, lalu dikupas hingga bersih kemudian diparut dengan menggunakan parutan kelapa steril. Hasil parutan disaring menggunakan kain kassa steril dan ditampung dalam erlenmeyer steril, Pembuatan larutan uji rebusan yaitu 250 gram rimpang lengkuas merah (Alpinia purpurata K.schum) dicuci dengan air mengalir kemudian ditiriskan, lalu dikupas hingga bersih kemudian direbus dengan aquadest sebanyak $250 \mathrm{ml}$ hingga mendidih. Hasil rebusan disaring menggunakan kain kassa steril dan ditampung dalam erlenmeyer steril.

b. Pengujian air rebusan serta air perasan lengkuas merah terhadap pertumbuhan jamur Trichophyton rubrum.

c. Mengamati zona hambat yang terbentuk pada masing-masing konsentrasi dan diukur menggunakan alat ukur jangka sorong dalam satuan $(\mathrm{mm})$.

Metode Pemeriksaan yang digunakan adalah Difusi Cakram dengan cara Kirby Bauer (Jawetz, 2008).

Data yang diperoleh dianalisis dengan cara melihat konsentrasi yang menghasilkan diameter zona hambat. Analisis data bertujuan untuk membandingkan terhambatnya pertumbuhan jamur Trichophyton rubrum dilihat dari rerata diameter zona hambat yang terbentuk dari masing-masing konsentrasi antara air perasan lengkuas merah (Alpinia purpurata K.schum) dan air rebusan lengkuas merah (Alpinia purpurata K.schum) pada metode difusi cara disc obat, dengan menggunakan uji ANOVA. Untuk melihat apakah kedua larutan uji memiliki daya antijamur dengan menggunakan uji $\mathrm{T}$.

\section{HASIL}

Setelah dilakukan uji daya hambat air rebusan dan air perasan lengkuas merah (Alpinia purpurata K.Schum) terhadap pertumbuhan jamur Trichophyton rubrum penyebab Tinea pedis (kutu air) diperoleh hasil bahwa hanya pada air perasan lengkuas merah (Alpinia purpurata K.Schum) yang terbentuk zona hambat (zona jernih) di sekitar disc, sedangkan pada air rebusan lengkuas merah (Alpinia purpurata K.Schum) tidak terbentuk zona hambat (zona jernih) disekitar disc. Zona hambat yang terbentuk diukur menggunakan jangka sorong dengan satuan $\mathrm{mm}$ (milimeter) seperti yang terdapat pada Tabel 1 .

Tabel 1. Diameter Zona Hambat Air Perasan Lengkuas Merah (Alpinia purpurata K.Schum) terhadap Pertumbuhan Jamur Trichophyton rubrum

\begin{tabular}{ccccccccccccc}
\hline \multirow{2}{*}{$\mathbf{n}$} & \multicolumn{10}{c}{ Zona hambat yang terbentuk di sekitar disc } \\
\cline { 2 - 13 } & $\mathbf{1 0 \%}$ & $\mathbf{2 0 \%}$ & $\mathbf{3 0 \%}$ & $\mathbf{4 0 \%}$ & $\mathbf{5 0 \%}$ & $\mathbf{6 0 \%}$ & $\mathbf{7 0 \%}$ & $\mathbf{8 0 \%}$ & $\mathbf{9 0 \%}$ & $\mathbf{1 0 0 \%}$ & $\mathbf{K}(+)$ & $\mathbf{K}(-)$ \\
\hline 1 & 24,25 & 24,68 & 25,01 & 25,56 & 25,96 & 26,46 & 27,00 & 27,68 & 28,11 & 28,89 & 41,09 & 0 \\
2 & 24,31 & 24,87 & 25,32 & 25,79 & 26,47 & 26,94 & 27,43 & 27,97 & 28,46 & 28,97 & 42,12 & 0 \\
3 & 24,54 & 24,85 & 25,19 & 25,63 & 26,34 & 26,85 & 27,12 & 27,77 & 28,15 & 28,93 & 41,32 & 0 \\
Jumlah & 73,10 & 74,40 & 75,52 & 79,98 & 78,77 & 80,25 & 81,55 & 83,42 & 84,72 & 86,79 & 124,53 & 0 \\
Rata2 & 24,37 & 24,80 & 25,17 & 25,66 & 26,26 & 26,75 & 27,18 & 27,81 & 28,24 & 28,93 & 41,51 & 0 \\
\hline
\end{tabular}

Tabel 1 menunjukkan bahwa air perasan lengkuas merah (Alpinia purpurata K.Schum) membentuk zona hambat, sedangkan air rebusan lengkuas merah (Alpinia purpurata K.Schum) tidak membentuk zona hambat. Ukuran rerata diameter zona hambat air perasan lengkuas merah (Alpinia purpurata K.Schum) yang terbesar dihasilkan oleh larutan dengan konsentrasi $100 \%$ yaitu sebesar $28,93 \mathrm{~mm}$. Pada tabel diatas juga terlihat adanya pertambahan diameter pada masing-masing konsentrasi yang menunjukkan bahwa besarnya diameter zona hambat berbanding lurus dengan peningkatan konsentrasi pada air perasan lengkuas merah (Alpinia purpurata K.Schum), sedangkan pada air rebusan lengkuas merah (Alpinia purpurata K.Schum) tidak menunjukkan adanya zona hambat.

Zona hambat yang terbentuk dari hasil uji daya hambat dilakukan pengkategorian kekuatan hambatnya, dengan hasil sebagai berikut: 
Tabel 2. Hasil Kategori Zona Hambat Uji Perasan Lengkuas Merah (Alpinia purpurata K.Schum) terhadap Pertumbuhan Jamur Trichophyton rubrum

\begin{tabular}{rrrc}
\hline & & Rerata & Kategori zona hambat \\
\hline Konsentrasi & $10 \%$ & 24,37 & Sangat kuat \\
& $20 \%$ & 24,80 & Sangat kuat \\
& $30 \%$ & 25,17 & Sangat kuat \\
$40 \%$ & 25,66 & Sangat kuat \\
$50 \%$ & 26,26 & Sangat kuat \\
$60 \%$ & 26,75 & Sangat kuat \\
$70 \%$ & 27,18 & Sangat kuat \\
$80 \%$ & 27,81 & Sangat kuat \\
$90 \%$ & 28,24 & Sangat kuat \\
$100 \%$ & 28,93 & Sangat kuat \\
\hline
\end{tabular}

Berdasarkan Tabel 2 diketahui dari konsentrasi $20 \%$ sampai dengan konsentrasi $100 \%$ memiliki kategori zona hambat yang sangat kuat (semua rerata zona hambat melebihi $20 \mathrm{~mm}$ ). Hasil penelitian selanjutnya dianalisa dengan menggunakan uji statistika yaitu uji Anova, sebelumnya data hasil penelitian diuji terlebih dahulu homogenitas dan variansnya serta normalitas datanya sebagai syarat untuk lanjut ke uji Anova. Hasil uji homogenitas dan varians didapatkan $p=0,171$. karena $p>0,05$ maka varians data pada uji air perasan lengkuas merah (Alpinia purpurata K.Schum) adalah sama dan data dinyatakan homogen. Hasil uji normalitas didapatkan $p>0,05$ maka data dinyatakan distribusinya normal. Kemudian data hasil penelitian air perasan lengkuas merah (Alpinia purpurata K.Schum) dilanjutkan ke uji Anova.

Tabel 3. Hasil Analisa One Way Anova Air Perasan Lengkuas Merah (Alpinia purpurata K.Schum) terhadap Pertumbuhan Jamur Trichophyton rubrum

\begin{tabular}{ccccc}
\hline & & $\mathbf{n}$ & Rerata \pm s.b. & $\boldsymbol{p}$-value \\
\hline Konsentrasi & $10 \%$ & 3 & $24,37 \pm 0,15$ & 0,000 \\
& $20 \%$ & 3 & $24,80 \pm 0,10$ & \\
$30 \%$ & 3 & $25,17 \pm 0,15$ & \\
$40 \%$ & 3 & $25,66 \pm 0,11$ & \\
$50 \%$ & 3 & $26,26 \pm 0,26$ & \\
$60 \%$ & 3 & $26,75 \pm 0,25$ & \\
$70 \%$ & 3 & $27,18 \pm 0,22$ & \\
$80 \%$ & 3 & $27,81 \pm 0,15$ & \\
$90 \%$ & 3 & $28,24 \pm 0,19$ & \\
$100 \%$ & 3 & $28,93 \pm 0,04$ & \\
\hline
\end{tabular}

Hasil uji Anova didapatkan $p=0,000$ maka $p<0,05$ yang berarti bahwa faktor mempengaruhi variabel, dimana konsentrasi air perasan sebagai faktor mempengaruhi zona hambat yang terbentuk sebagai variabelnya. Untuk melihat kelompok mana yang mempengaruhi secara bermakna kemudian dilanjutkan ke analisa PostHoc Least Significant Difference (LSD) atau uji Beda Nyata Terkecil (BNT).

Dari hasil analisa Post-Hoc (LSD) atau uji Beda Nyata Terkecil (BNT) didapatkan semua $p<0,05$ disetiap konsentrasi dan ini menunjukkan dari semua kelompok konsentrasi memberikan pengaruh yang nyata atau semua kelompok memiliki perbedaan yang bermakna.

Untuk uji efektifitas air rebusan lengkuas merah (Alpiniapurpurata K.Schum) karena tidak adanya zona hambat yang terbentuk maka tidak dilanjutkan untuk analisa data uji Anova maupun uji Beda Nyata Terkecil (BNT).

Setelah dilakukan uji Anova dan uji Beda Nyata Terkecil (BNT) pada data hasil uji, selanjutnya membandingkan antara hasil uji rebusan lengkuas merah (Alpinia purpurata K.Schum) dan hasil uji perasan lengkuas merah (Alpinia purpurata K.Schum). untuk membandingkan ke dua uji tersebut seharusnya menggunakan uji t tidak berpasangan, namun karena data hasil rebusan tidak ada zona hambat yang terbentuk maka tidak perlu dilakukan uji $\mathrm{t}$ tidak berpasangan.

\section{PEMBAHASAN}

Hasil penelitian uji daya hambat air rebusan dan air perasan lengkuas merah (Alpinia purpurata K.Schum) terhadap pertumbuhan jamur Trichophyton rubrum penyebab kutu air (Tinea pedis) menunjukkan bahwa hanya pada air perasan lengkuas merah (Alpinia purpurata K.Schum) yang menghasilkan zona hambat sedangkan pada air rebusan lengkuas merah (Alpinia purpurata K.Schum) tidak menghasilkan zona hambat.

Melalui metode difusi menunjukkan bahwa air perasan lengkuas merah (Alpinia purpurata K.Schum) pada setiap konsentrasi memiliki zona hambat dengan kategori sangat kuat. Pada konsentrasi $10 \%$ menghasilkan zona hambat dengan rerata $24,37 \mathrm{~mm}$, konsentrasi $20 \%$ menghasilkan zona hambat dengan rerata 24,80 $\mathrm{mm}$, konsentrasi $30 \%$ didapatkan rerata zona hambat sebesar $25,17 \mathrm{~mm}$, konsentrasi $40 \%$ didapatkan zona hambat dengan rerata sebesar 25,66 mm, konsentrasi 50\% didapatkan zona hambat dengan rerata $26,26 \mathrm{~mm}$ konsentrasi $60 \%$ 
menghasilkan zona hambat dengan rerata 26,75 $\mathrm{mm}$, konsentrasi $70 \%$ menghasilkan zona hambat dengan rerata $27,18 \mathrm{~mm}$, konsentrasi $80 \%$ didapatkan rerata zona hambat sebesar 27,81 $\mathrm{mm}$, konsentrasi $90 \%$ didapatkan zona hambat dengan rerata sebesar $28,24 \mathrm{~mm}$, dan konsentrasi $100 \%$ didapatkan zona hambat dengan rerata $28,93 \mathrm{~mm}$.

Berdasarkan hasil diameter zona hambat yang terbentuk semakin besar konsentrasi maka semakin besar kemampuan air perasan lengkuas merah (Alpinia purpurata K.Schum) dalam menghambat pertumbuhan jamur Trichophyton rubrum. Hal ini sejalan dengan hasil analisa uji anova pada air perasan lengkuas merah (Alpinia purpurata K.Schum) menunjukkan bahwa $p$ value $<0,05$, yang berarti bahwa faktor mempengaruhi variabel dimana konsentrasi air perasan sebagai faktor mempengaruhi zona hambat yang terbentuk sebagai variabelnya.

Dari hasil analisa Post-Hoc (LSD) atau uji beda nyata terkecil didapatkan semua $p$-value< 0,05 disetiap konsentrasi dan ini menunjukkan dari semua kelompok konsentrasi memberikan pengaruh yang nyata. Hal ini menunjukkan bahwa dari konsentrasi 10\%, 20\%, 30\%, 40\%, $50 \%, \quad 60 \% 70 \%, 80 \%, \quad 90 \%$ dan $100 \%$ memberikan pengaruh yang nyata dalamm enghambat pertumbuhan jamur Trichophyton rubrum. Pada konsentrasi $100 \%$ didapatkan zona hambat yang lebih besar dibandingkan dengan konsentrasi yang lainnya, hal ini dikarenakan belum adanya proses pengenceran sehingga senyawa yang terkandung dalam konsentrasi $100 \%$ lebih banyak dan zona hambat yang dibentuk lebih besar dibandingkan konsentrasi yang lainnya.

Berdasarkan keseluruhan hasil penelitian yang telah dilakukan peneliti dapat diketahui bahwa air rebusan lengkuas merah (Alpinia purpurata K.Schum) tidak menghasilkan zona hambat di sekitar disc sedangkan air perasan lengkuas merah (Alpinia purpurata K.Schum) menghasilkan zona hambat yang ditandai dengan terbentuknya zona hambat (zona jernih) di sekitar disc. Hal ini dikarenakan jumlah kandungan senyawa yang terdapat pada air rebusan lengkuas merah (Alpinia purpurata K.Schum) dan air perasan lengkuas merah (Alpinia purpurata K.Schum) berbeda.

Pada air rebusan lengkuas merah (Alpinia purpurata K.Schum) tidak menghasilkan zona hambat di sekitar disc, hal tersebut disebabkan oleh minimnya kandungan senyawa zat aktif yang terdapat di dalam air rebusan. Komponen bioaktif yang terkandung dalam lengkuas merah (Alpinia purpurata K.Schum) terbanyak adalah dari jenis terpenoid dan flavonoid. Dimana golongan terpenoid memiliki titik didih yang tinggi $\left(140^{\circ} \mathrm{C}-180^{\circ} \mathrm{C}\right)$ namun sukar larut dalam air (Hanani, 2016). Sehingga diperkirakan walaupun senyawa golongan terpenoid ini tidak terpengaruh pada suhu perebusan namun senyawa ini tidak ikut larut dalam air pada saat perebusan, sehingga senyawa golongan terpenoid ini tidak terkandung dalam air rebusan. Golongan flavonoid yang terdapat pada lengkuas merah (Alpinia purpurata K.Schum) memiliki titik didih yang rendah yaitu $64^{\circ} \mathrm{C}$, walaupun perebusan hanya memakai suhu $60^{\circ} \mathrm{C}$ namun tetap tidak dapat menghambat pertumbuhan jamur Trichophyton rubrum. Hal ini dikarenakan kandungan senyawa flavonoid di dalam air rebusan tidak berfungsi atau mengalami penurunan sebagai zat aktif. Senyawa flavonoid tidak stabil terhadap perubahan pengaruh oksidasi, cahaya, dan perubahan kimia, dan apabila teroksidasi strukturnya akan berubah dan fungsinya sebagai bahan aktif akan menurun bahkan hilang dan kelarutannya rendah (Hanani, 2016)

Pada air perasan lengkuas merah (Alpinia purpurata K.Schum) menghasilkan zona hambat di sekitar disc. Komponen bioaktif pada rempahrempah, khususnya pada golongan Zingeberaceae yang terbanyak adalah dari jenis terpenoid dan flavonoid. Komponen lainnya yang terdapat pada golongan Alpinia adalah alpinetin. Alpinetin merupakan jenis flavanon yang dikenal sebagai senyawa fungistatik dan fungisida. Bentuk senyawa bioaktif lainnya adalah dari golongan terpenoid. Golongan ini merupakan kelompok utama pada tanaman sebagai penyusun minyak atsiri (Bohm, 1975 dalam Budiarti, 2006).

Komponen antimikroba dalam rempahrempah adalah senyawa fenolik. Senyawa fenolik umumnya terdapat dalam minyak atsiri. Fenol merupakan monoterpen yang pada umumnya digunakan sebagai bahan antiseptik. Sedangkan beberapa senyawa terpen lainnya yang memiliki struktur sikloheksana dengan gugus hidroksil serta penambahan gugus lainnya juga memiliki kemampuan yang sama dalam menghambat kapang,khamir,dan bakteri (Shelef 1983 dalam Budiarti, 2006).

Mekanisme penghambatan pertumbuhan jamur Trichophyton rubrum melalui perusakan permeabelitas membrane sel. Kerusakan membran sel dapat menyebabkan kebocoran sehingga kompenen-kompenen penting di dalam sel seperti protein, asam nukleat, nukleotida dan lain-lain dapat mengalir keluar. Hal ini menyebabkan permeabilitas sel terganggu 
sehingga sel tidak dapat melakukan aktivitas hidup dan pertumbuhannya terhambat atau bahkan mati (Setyarini, 2011).

Ketika membandingkan antara air rebusan lengkuas merah (Alpinia purpurata K.Schum) dan air perasan lengkuas merah (Alpinia purpurata K.Schum) dapat diketahui bahwa air perasan lengkuas merah (Alpinia purpurata K.Schum) lebih baik dibandingkan dengan air rebusan lengkuas merah (Alpinia purpurata K.Schum). Air perasan lengkuas merah tidak hanya dapat menghambat pertumbuhan jamur Trichophyton rubrum namun dapat menghambat pertumbuhan jamur lainnya seperti pada penelitian (Afriliya, 2008) yang berjudul uji daya hambat air perasan lengkuas merah terhadap jamur Microsporum gypseum, air perasan lengkuas merah dapat menghambat pertumbuhan jamur Microsporum gypseumpada konsentrasi minimum $10 \%$ dengan zona hambat $15,33 \mathrm{~mm}$.

Air perasan lengkuas merah (Alpinia purpurata K.Schum) jika dibandingkan dengan kontrol maka dinyatakan tidak efektif dikarenakan zona hambat yang terbentuk tidak ada yang melebihi dari zona hambat yang terbentuk pada kontrol positif. Hal ini dikarenakan kontrol positif merupakan suatu zat antifungi murni. Pada penelitian ini senyawa antifungi dari lengkuas belum dapat dipisahkan dari senyawa-senyawa lain seperti karbohidrat, protein dan lemak yang berfungsi sebagai nutrisi bagi jamur, sehingga air perasan yang didapatkan tidak semaksimal kontrol positif dalam

\section{DAFTAR PUSTAKA}

Afriliya, E. 2008. Uji Daya Hambat Air Perasan Lengkuas Merah terhadap Jamur Microsporum gypseum. [Karya Tulis Ilmiah]. Bandar Lampung: Jurusan Analis Kesehatan, Politeknik Kesehatan Tanjungkarang.

Apsari A, S., Adiguna, M, S. 2013. Resistensi Antijamur dan Strategi untuk Mengatasi. Jurnal MDVI, vol 40 No. 2: 89-95.

Baheramsyah. 2014. Tumbuhan Obat Disekitar Rumah Kita. Lampung: Lampung Herba Center.

Budiarti, R. 2006. Pemanfaatan Lengkuas Merah Sebagai Bahan Anti Jamur Dalam Sampo. [Skripsi]. Bogor: Fakultas Teknologi Pertanian, Instititut Pertanian Bogor.

Hanani E, 2016. Analisis Fitokimia. Jakarta: Buku Kedokteran. menghambat pertumbuhan jamur (Setyarini, 2011).

\section{SIMPULAN}

Air rebusan lengkuas merah (Alpinia purpurata K.Schum) tidak efektif bila dibandingkan dengan air perasan lengkuas merah (Alpinia purpurata K.Schum) dalam menghambat pertumbuhan jamur Trichophyton rubrum penyebab kutu air).

\section{SARAN}

1. Bagi Masyarakat dianjurkan untuk menggunakan air perasan lengkuas merah (Alpinia purpurata K.Schum) dibandingkan dengan air rebusan lengkuas merah (Alpinia purpurata K.Schum) dalam pengobatan infeksi Trychophyton rubrum penyebab kutu air (tinea pedis).

2. Perlu dilakukan penelitian lanjutan pada air rebusan lengkuas merah dengan menggunakan sediaan kering dalam menghambat pertumbuhan jamur Trychophyton rubrum atau dengan metode Teknik ekstraksi dan fraksinasi.

Jawetz; Melnick; Adelberg. 2008. Mikrobiologi Kedokteran, Edisi 23. Jakarta: Penerbit Buku Kedokteran EGC.

Priyoto, dkk. 2014. Pengobatan Herbal untuk Penyakit Ringan Yogyakarta: Graha ilmu.

Setyarini, P, S., Krisnansari, D. 2011. Perbandingan Efek Antifungi Ekstrak Lengkuas (Alpinia galangal linn) dengan Ketokenazol pada Isolat Malassezia furfur. Mandala of Health, Vol 4 (1):52-57

Sondakh, C. E., Pandaleke, T. A., \& Mawu, F. O. 2016. Profil dermatofitosis di Poliklinik Kulit dan Kelamin RSUP Prof. Dr. RD Kandou Manado periode JanuariDesember 2013. e-CliniC, 4(1). 
Sutanto, dkk. 2008. Parasitologi Kedokteran edisi ke-4. Jakarta: Penerbit FKUI.

Violita, Y. 2013. Perbandingan Uji Efektivitas Air Perasan Lengkuas Merah Dengan Air Perasan Lengkuas Putih Terhadap
Pertumbuhan Jamur Malessezia furfur Penyebab Panu. [Skripsi]. Bandar Lampung: Jurusan Analis Kesehatan, Politeknik Kesehatan Tanjungkarang. 